
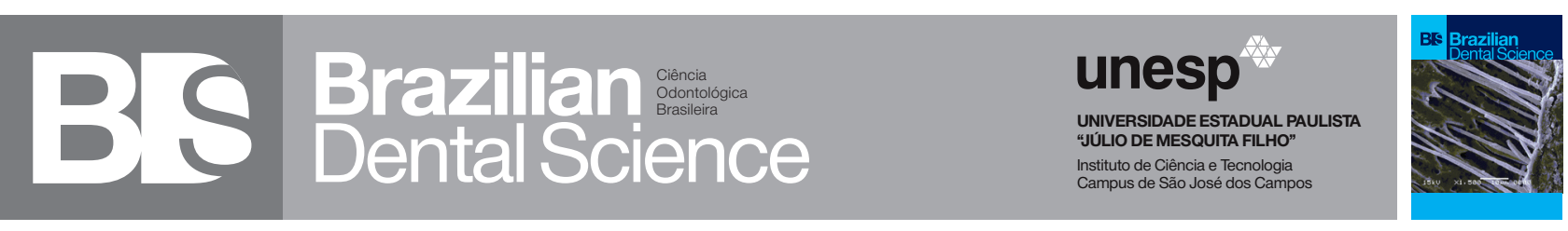

\title{
Apical periodontitis in relation to radiographic quality of endodontic treatment in a selected adult Turkish population: a cross-sectional study
}

Periodontite apical em relação à qualidade radiográfica do tratamento endodôntico em uma amostra da população adulta turca: um estudo transversal

Güzide P. SEZGIN ${ }^{1}$; Sema SÖNMEZ-KAPLAN ${ }^{1}$, Tuna KAPLAN ${ }^{1}$

1 - Department of Endodontics - Faculty of Dentistry - Biruni University - Istambul - Turkey.

\begin{abstract}
Objective: The aim of this study was to examine the quality of root canal fillings and their relationship with apical periodontitis (AP) in a selected Turkish population. Material and Methods: The cases in this study was formed of patients attending routine dental treatment at the Faculty of Dentistry, University of Birun. 1024 patients were examined with panoramic radiographs and 1780 endodontically treated teeth with present periapical radiographs. Endodontic treatment quality was evaluated by obturation length, density, taper quality and iatrogenic errors. Presence of AP was analysed according to Ørstavik's periapical index (PAI). The chi-square test was used for statistical analyses. Results: Statistically significant relationship was found between both the tooth type and location with obturation quality (p: $0.000 ; p<0.05)$. Obturation quality of maxillary and mandibular molars are significantly less than the other tooth types in the same location. Apical periodontitis were noticed in 740 teeth (41.6\%). Inadequate obturation quality was found to be significantly effective on the periapical status of tooth types both in maxilla and mandible ( $\mathrm{p}<0.05)$. Conclusion: The frequency of inadequate root canal obturations of endodontically treated teeth of the selected Turkish population was high, especially in molar teeth and women. Even though radiographic obturation quality is not the only success criteria in endodontic treatment, it is still one of the most important criteria regarding the positive correlation of "inadequate" obturations with AP.
\end{abstract}

\section{KEYWORDS}

Periapical periodontitis; Radiography; Root canal obturation; Root canal theraphy.

\section{RESUIMO}

Objetivo: O objetivo deste estudo foi examinar a qualidade dos preenchimentos do canal radicular e sua relação com a periodontite apical (PA) em uma amostra da população turca. Material e Métodos: Os casos deste estudo foram formados por pacientes em tratamento odontológico de rotina na Faculdade de Odontologia da Universidade de Birun. Mil e vinte e quatro pacientes foram examinados com radiografias panorâmicas e 1780 dentes tratados endodonticamente com radiografias periapicais presentes. A qualidade do tratamento endodôntico foi avaliada pelo comprimento da obturação, densidade, qualidade do cone e erros iatrogênicos. A presença de PA foi analisada de acordo com o índice periapical de Ørstavik (IPA). O teste do qui-quadrado foi utilizado para análises estatísticas. Resultados: Foi encontrada relação estatisticamente significante entre o tipo e a localização do dente com a qualidade da obturação (p: 0,000; $p<0,05$ ). A qualidade da obturação dos molares superiores e inferiores é significativamente menor que os outros tipos de dentes no mesmo local. Periodontite apical foi observada em 740 dentes $(41,6 \%)$. A qualidade inadequada da obturação mostrou ser significativamente eficaz no estado periapical dos tipos de dentes, tanto na maxila quanto na mandíbula ( $\mathrm{p}<0,05)$. Conclusão: A frequência de obturação inadequada do canal radicular de dentes tratados endodonticamente na população turca selecionada foi alta, principalmente em dentes molares e mulheres. Embora a qualidade da obturação radiográfica não seja o único critério de sucesso no tratamento endodôntico, ainda é um dos critérios mais importantes em relação à correlação positiva das obturações "inadequadas" com a PA.

\section{PALAVRAS-CHAVE}

Periodontite periapical; Radiografia; Obturação do canal radicular; Terapia do canal radicular. 


\section{INTRODUCTION}

A pical periodontitis (AP) is an inflammatory status of the periapical tissues that might evolve if microorganisms are introduced into the pulp tissue [1]. The aim of endodontic therapy is either to inhibit AP or to provide the survival of teeth for a long time. Different studies indicated that the prevalance of root canal treatment ranged from $22 \%$ to $\% 72$ and most of AP cases appear to be located in formerly endodontically treated teeth [2-4]. Besides, the existence of AP in root canal treated teeth after a certain time might be recognized as evidence of endodontic treatment failure.

Periapical health and healing depend on the quality of root canal filling. The quality of endodontic therapy is primarily based on radiographic assesment. Radiographic evaluation provides length, density, taper and homogeneity of the root canal obturation [5]. Various follow-up studies assessing the outcome of root canal therapy have demonstrated that the prognosis was positively correlated with the technical quality of the root canal obturation [68]. Detection of disease prevalence is the aim of the descriptive epidemiological examinations that are most frequently performed as crosssectional researches [9]. A descriptive approach with a cross-sectional study model is generally used in studies of the success and quality of root canal therapy, too [10]. Data from these studies might be very beneficial in the assessment and designing of dental education as well as in dental care planning [11].

The results of many controlled clinical studies have demonstrated that the success rate of endodontic theraphies may be very high [10,12-14]. Conversely, epidemiological studies have recorded an extensively decreased success rate in the general population [15-17]. Solid correlation has been discovered in all of these tests between root canal obturation and the frequency of AP. Each epidemiologically based examination noted significant rates of inadequate root canal obturations in analyzed populations [18].
Studies into the relationship between AP and the quality of performed endodontic therapy are limited in Turkey. Considering the fact that this data might be valuable for the assessment of performed root canal therapies as well as for dental care planning and the inadequacy of such information. The aim of this study was to examine the quality of root canal fillings as well as their relationship with periapical pathosis in a selected group of patients from Turkey.

\section{MATERIAL AND METHODS}

The Ethical Board of University of Biruni approved the study (2018/23-17). The cases in this cross-sectional study were formed of patients attending routine dental treatment at the School of Dental Medicine, University of Biruni, for the first time during the period of November 5, 2018, to December 17, 2018. All patients included in present study were over 18 years old. The patient records examined for this study were randomly chosen from the patient record pools of dental clinics. Data were obtained retrospectively from the database system including age, sex, medical and dental histories of patients.

The main inclusion criteria in the study was the availability of a panoramic radiograph and a periapical radiograph taken from the section of the endodontically treated tooth. No endodontic treatment for at least one year was another inclusion criterion. Also, individuals whose radiographs were difficult to read were excluded.

\section{Evaluation criteria}

The patient features were obtained in an individually structured form including general and dental information sections specifically designed for this examination. Dental information was collected by radiological examination and focused on the quality of root canal obturation.

Teeth were classified as endodontically treated if radiopaque material was observed in the pulp chamber and/or root canal(s). Root canal obturation length and density were examined on 
the basis of European Society of Endodontology guidelines [19]. Additional criterias as taper quality and presence of iatrogenic errors based on the study by Barrieshi-Nusair et al. [20] were also evaluated. Root canal obturations ending within $2 \mathrm{~mm}$ from the radiological apex with no visible voids and consistent taper from the coronal to the apical part of the filling with good reflect to canal shape with no iatrogenic errors, were categorized as adequate. Underfilled, overfilled, poorly condensed root canal fillings, cases with inadequate preparation tapers and iatrogenic errors such as ledge, perforation and fractured instrument presence were categorized as inadequate. Periapical status was evaluated using the periapical index (PAI) proposed by $\emptyset$ rstavik et al. [21] who graded the apical region of the radiographs as below:

\section{Normal periapical structures;}

2. Small changes in bone structure;

3. Changes in bone structure with some mineral loss;

4. Periodontitis with well defined radiolucent area;

5. Severe periodontitis with exacerabating features.

Multirooted teeth were categorized according to the root with the highest score.

\section{Radiographic examination}

All radiographs were taken by experienced radiography assistants. Panoramic radiographs were taken with a Sirona Galileos panoramic x-ray unit (Sirona, Bensheim, Germany). Periapical radiographs were taken by using a phosphor-plate radiography system (Dürr Dental, Bietigheim-Bissingen, Germany) with the image plate and film holder system (Dürr Dental, Bietigheim-Bissingen, Germany) with parallel technique for standardization. 1024 patients were examined with panoramic radiographs, and 1780 endodontically treated teeth with present periapical radiographs. The radiographs were examined by two experienced endodontists. The final decisions on PAI grades were made based on periapical radiographs. In case of any disagreement about the PAI grades, a third experienced endodontist was consulted in order to reach agreement.

Radiographs were analyzed with PACS (Picture Archiving and Communication Systems) Software version (1.1.1.6) for Windows 10 (Microsoft Corporation, Redmont, WA, USA) and displayed on a 28inch Samsung LU28H750UQMXUF monitor (Samsung Electronics, Seul, South Korea) with a 3840*2160 pixel resolution. For observer calibration, one set of randomly selected 200 reference teeth panoramic and periapical radiographs were used. Inter-observer consensus for all parameters was evaluated by calculating Cohen's Kappa scores. All Kappa scores were between 0.85 and 0.9 , signifying a high degree of agreement. Intra-observer consensus with a 2-month interval was performed.

\section{Statistical analysis}

Data were analyzed using the IBM SPSS Statistics 22 (IBM SPSS, Turkey) program. The chi-square test was used to analyse the differences between the groups. The level of statistical significance was set at $5 \%(\mathrm{p}<0.05)$.

\section{RESULTS}

$724(70.7 \%)$ of 1024 patients were suitable for inclusion criterias of this study while 300 patients $(29.3 \%)$ were not suitable. The general information concerned the individuals' age and gender. Five age groups were designated (a: $18-29$, b: 30-39, c: 40-49, d: 50-59, e: over 60 years) (Table I). The distribution of study parameters is shown in Table II. 724 patients, ranging in age from 18 to 85 years, were evaluated; of them, 310 (42.9\%) were male and $414(57.1 \%)$ female. The biggest age group (34\%) consisted of those between the ages of 18 and 29. A total of 1780 endodontically-treated teeth were examined. Study parameters were location by jaw, tooth type, obturation length, obturation density, taper quality, iatrogenic errors (ledge, perforation, instrument fracture), obturation quality and periapical index score. 
Among the tooth types, the highest incidence of root canal treatment was noted in the molar teeth $(42,4 \%)$ and the lowest in the canines $(7 \%)$. The percentage of teeth with root canal treatment was more in maxilla $(58,4 \%)$ than mandible $(41,6 \%)$.

Table I - Gender and age distrubution of the population

\begin{tabular}{|c|c|c|c|}
\hline & & $\mathbf{n}$ & $\%$ \\
\hline \multirow{5}{*}{ Age group } & $18-29$ & 246 & 34 \\
\hline & 30-39 & 202 & 27.9 \\
\hline & $40-49$ & 150 & 20.7 \\
\hline & $50-59$ & 74 & 10.2 \\
\hline & $60+$ & 52 & 7.2 \\
\hline \multirow{2}{*}{ Gender } & Male & 310 & 42.9 \\
\hline & Female & 414 & 57.1 \\
\hline
\end{tabular}

Table II - Distribution of study parameters

\begin{tabular}{|c|c|c|c|}
\hline & & $\mathbf{n}$ & $\%$ \\
\hline \multirow{2}{*}{ Location } & Maxilla & 1040 & 58.4 \\
\hline & Mandible & 740 & 41.6 \\
\hline \multirow{4}{*}{ Tooth type } & Incisor & 258 & 14.5 \\
\hline & Canine & 124 & 7 \\
\hline & Premolar & 644 & 36.2 \\
\hline & Molar & 754 & 42.4 \\
\hline \multirow{3}{*}{$\begin{array}{l}\text { Obturation } \\
\text { length }\end{array}$} & Proper & 934 & 52.5 \\
\hline & Overfilled & 56 & 3.1 \\
\hline & Underfilled & 790 & 44.4 \\
\hline \multirow{2}{*}{ Density } & No voids & 770 & 43.3 \\
\hline & Voids & 1010 & 56.7 \\
\hline \multirow{2}{*}{ Taper quality } & Adequate & 830 & 46.6 \\
\hline & Inadequate & 950 & 53.4 \\
\hline \multirow{4}{*}{ latrogenic error } & No & 1680 & 94.4 \\
\hline & Ledge & 8 & 0.4 \\
\hline & Perforation & 4 & 0.2 \\
\hline & $\begin{array}{l}\text { Fractured } \\
\text { Instrument }\end{array}$ & 88 & 4.9 \\
\hline \multirow{2}{*}{$\begin{array}{l}\text { Obturation } \\
\text { quality }\end{array}$} & Adequate & 524 & 29.4 \\
\hline & Inadequate & 1256 & 70.6 \\
\hline \multirow{5}{*}{ PAlscore } & 1 & 1680 & 94.4 \\
\hline & 2 & 8 & 0.4 \\
\hline & 3 & 4 & 0.2 \\
\hline & 4 & 88 & 4.9 \\
\hline & 5 & 88 & 4.9 \\
\hline
\end{tabular}

\section{Quality of endodontic treatment}

Statistically significant correlation was found between both tooth type and location with obturation quality (p: $0.000 ; \mathrm{p}<0.05$ ). Obturation quality of maxillary molars (13.7\%) is significantly less than maxillary anteriors $(33.3 \%)$, canines $(22.7 \%)$ and premolars $(36.2 \%)$. On the other hand, obturation quality of mandibular canines (11.1\%) was found to be less than mandibular anteriors (58.3\%), premolars (33.3\%) and molars (31.7\%) (p < 0.05). Maxillary canine and molar teeth had 1.27 and 3.18 times higher risk of inadequate obturation quality in comparison with the other types of maxillary teeth, respectively. Moreover, mandibular canine and molar teeth had 4.13 and 1.13 times higher risk for inadequate obturation quality than the other mandibular tooth types, respectively (Table III).

Table III - Distribution of obturation quality according to tooth type and location

\begin{tabular}{|c|c|c|c|c|c|}
\hline & \multicolumn{2}{|c|}{ Obturation quality } & \multirow{3}{*}{ OR (95\% Cl) } & \multirow{3}{*}{ p } \\
\hline & & \multicolumn{2}{|c|}{ Adequate Inadequate } & & \\
\hline & & $n(\%)$ & $n(\%)$ & & \\
\hline \multirow{4}{*}{ Maxillary } & Incisor & $70(33.3 \%)$ & $140(66.7 \%)$ & $0.677(0.489-0.939)$ & \multirow[t]{4}{*}{$0.000^{\star}$} \\
\hline & Canine & $20(22.7 \%)$ & $68(77.3 \%)$ & $1.277(0.761-2.146)$ & \\
\hline & Premolar & $142(36.2 \%)$ & 250 (63.8\%) & $0.476(0.360-0.630)$ & \\
\hline & Molar & $48(13.7 \%)$ & $302(86.3 \%)$ & $3.187(2.261-4.491)$ & \\
\hline \multirow{4}{*}{ Mandibular } & Incisor & $28(58.3 \%)$ & $20(41.7 \%)$ & $0.324(0.179-0.588)$ & \multirow[t]{4}{*}{$0.000^{*}$} \\
\hline & Canine & $4(11.1 \%)$ & $32(88.9 \%)$ & $4.138(1.447-11.837)$ & \\
\hline & Premolar & $84(33.3 \%)$ & $168(66.7 \%)$ & $0.976(0.706-1.348)$ & \\
\hline & Molar & $128(31.7 \%)$ & $276(68.3 \%)$ & $1.137(0.836-1.546)$ & \\
\hline
\end{tabular}

Chi-Square test / ${ }^{*} p<0.05$

\section{Periapical status}

According to PAI scoring, 1040 teeth (58.4\%) scored 1, 554 teeth (31.1\%) scored 2, 132 teeth (7.4\%) 3, 44 teeth (2.5\%) 4, and 10 teeth $(0.6 \%) 5$. The percentage of teeth scored with PAI 1 followed by PAI 2 were significantly higher than the teeth scored with PAI 3,4 and 5 ( $\mathrm{p}<0.05)$. There was a significant positive corelation between the PAI score and obturation quality: adequately obturated teeth tended to have PAI 1 score (p: 0.000; p < 0.05) (Table IV). 
Table IV - Distribution of periapical status according to obturation quality

\begin{tabular}{ccccccc} 
Obturation & $\mathbf{5}$ & $\mathbf{2}$ & $\mathbf{3}$ & $\mathbf{4}$ & $\mathbf{5}$ & $\mathbf{p}$ \\
Quality & $\mathbf{n ( \% )}$ & $\mathbf{n ( \% )}$ & $\mathbf{n ( \% )}$ & $\mathbf{n ( \% )}$ & $\mathbf{n ( \% )}$ & \\
& $\mathbf{n ( \%}(\%)$ & $104(19.8 \%)$ & $36(6.9 \%)$ & $0(0 \%)$ & $2(0.4 \%)$ & $0.000^{*}$ \\
Adequate & $382(72.9 \%)$ & & \\
Inadequate & $658(52.4 \%)$ & $450(35.8 \%)$ & $96(7.6 \%)$ & $44(3.5 \%)$ & $8(0.6 \%)$ & \\
\hline Total & $1040(58.4 \%)$ & $554(31.1 \%)$ & $132(7.4 \%)$ & $44(2.5 \%)$ & $10(0.6 \%)$ & $0.000^{*}$
\end{tabular}

Chi-square test / ${ }^{*} p<0.05$

One sample Chi-square test $/{ }^{*} p<0.05$

In Table $\mathrm{V}$, the association between the criteria registered for obturation quality and periapical status laid out. It shows that over-filled and under-filled obturations, density problems, inadequate taper quality and iatrogenic errors all had a significant negative effect on periapical status ( $\mathrm{p}<0.05)$. Hence, over-filled and underfilled obturations increased the AP risk 2.17 and 2.44 times, respectively. Also, oburations with voids and inadequate preparation tapers negatively affected periapical status 2.494 and 2.11 times, respectively $(\mathrm{p}<0.05)$.

Table V - Distribution of periapical status according to obturation criteria

\begin{tabular}{|c|c|c|c|c|c|}
\hline & & $\begin{array}{c}\text { AP } \\
\text { Absence } \\
n(\%)\end{array}$ & $\begin{array}{c}\text { AP } \\
\text { Presence } \\
\mathbf{n}(\%)\end{array}$ & OR $(95 \% \mathrm{Cl})$ & p \\
\hline \multirow{3}{*}{$\begin{array}{l}\text { Obturation } \\
\text { length }\end{array}$} & Proper & $640(68.5 \%)$ & $294(31.5 \%)$ & - & \multirow[t]{3}{*}{$0.000^{*}$} \\
\hline & Overfilling & $28(50 \%)$ & $28(50 \%)$ & $2.177(1.266-3.742)$ & \\
\hline & Underfilling & $372(47.1 \%)$ & $418(52.9 \%)$ & $2.446(2.010-2.977)$ & \\
\hline \multirow{2}{*}{ Density } & No voids & $544(70.6 \%)$ & 226 (29.4\%) & \multirow[t]{2}{*}{$2.494(2.046-3.041)$} & \multirow[t]{2}{*}{$0.000^{\circ}$} \\
\hline & Voids & $496(49.1 \%)$ & $514(50.9 \%)$ & & \\
\hline
\end{tabular}

Chi-Square test $/{ }^{*} p<0.05$

Regarding tooth type and periapical status, a statistically significant correlation was found (p: 0.000; $\mathrm{p}<0.05$ ). According to this result, both maxillary and mandibular molars with $\mathrm{AP}$, were found to be greater in number than maxillary and mandibular anteriors, canines and premolars with AP ( $p<0.05)$. No significant difference was noted among the other tooth types in mandible ( $p>0.05)$. On the other hand maxillary anteriors were found to have significantly more
AP than maxillary premolars (p: $0.011 ; \mathrm{p}<$ 0.05). Maxillary anterior teeth had 1.1 times higher risk for AP, and molar teeth 1.81 times, in comparison with the other tooth types of maxilla. Mandibular molar teeth had 3.09 times higher risk of AP (Table VI).

Table VI- Periapical status according to tooth type and location

\begin{tabular}{|c|c|c|c|c|c|}
\hline & & $\begin{array}{c}\text { AP } \\
\text { Absence } \\
\mathrm{n}(\%)\end{array}$ & $\begin{array}{c}\text { AP } \\
\text { Presence } \\
\text { n(\%) }\end{array}$ & OR (95\% Cl) & p \\
\hline \multirow{4}{*}{ Maxillary } & Incisor & $124(59 \%)$ & $86(41 \%)$ & $1.105(0.812-1.505)$ & \multirow[t]{4}{*}{$0.000^{*}$} \\
\hline & Canine & $58(65.9 \%)$ & $30(34.1 \%)$ & $0.792(0.500-1.255)$ & \\
\hline & Premolar & $272(69.4 \%)$ & $120(30.6 \%)$ & $0.558(0.428-0.728)$ & \\
\hline & Molar & $180(51.4 \%)$ & $170(48.6 \%)$ & $1.817(1.398-2.361)$ & \\
\hline \multirow{4}{*}{ Mandibular } & Incisor & $34(70.8 \%)$ & $14(29.2 \%)$ & $0.479(0.252-0.908)$ & \multirow[t]{4}{*}{$0.000^{*}$} \\
\hline & Canine & $26(72.2 \%)$ & $10(27.8 \%)$ & $0.451(0.214-0.949)$ & \\
\hline & Premolar & $174(69 \%)$ & $78(31 \%)$ & $0.406(0.295-0.560)$ & \\
\hline & Molar & $172(42.6 \%)$ & $232(57.4 \%)$ & 3.094 (2.281-4.198) & \\
\hline
\end{tabular}

Chi-Square test / ${ }^{*} p<0.05$

Statistical analysis of the data in Table VII revealed periapical status in relation to endodontic treatment quality and tooth type by location. It showed that inadequate obturation quality was found to significantly affect the periapical status of types of maxillary teeth (p: 0.001; p < 0.05). Inadequately obturated maxillary incisors with AP (50\%) were found to be significantly more numerous than inadequately obturated maxillary canines (35.3\%) and premolars (36.8\%) with AP $(\mathrm{p}<0.05)$. In addition, inadequately obturated maxillary molars with AP (51.7\%) were significantly more numerous than inadequately obturated maxillary canines (35.3\%) and premolars (36.8\%) with AP ( $\mathrm{p}<0.05)$. This means that the risk of AP in maxillary incisors and molars with inadequate obturation are 1.279 and 1.563 times higher than other inadequately obturated maxillary teeth with AP, respectively. On the other hand, there is a statistically significant correlation between tooth type and periapical health in inadequately obturated mandibular teeth. In this manner, mandibular molar teeth with inadequate obturation tend to be 3.307 times more risky than other inadequately 
obturated mandibular teeth with AP. Also, even where the obturation quality is adequate, there is a positive correlation between AP and tooth types in mandible. Thus, mandibular molar teeth with adequate obturation has a 2.797 times higher risk of AP.

Table VII - Periapical status according to obturation quality, tooth type and location

\begin{tabular}{|c|c|c|c|c|c|c|}
\hline Location & $\begin{array}{c}\text { Obturation } \\
\text { Quality }\end{array}$ & & $\begin{array}{c}\text { AP } \\
\text { Absence } \\
\text { n(\%) }\end{array}$ & $\begin{array}{c}\text { AP } \\
\text { Presence } \\
\text { n(\%) }\end{array}$ & OR $(95 \% \mathrm{Cl})$ & p \\
\hline \multirow{8}{*}{ Maxillary } & \multirow{4}{*}{ Adequate } & Incisor & $54(77.1 \%)$ & $16(22.9 \%)$ & & \multirow[t]{4}{*}{0.483} \\
\hline & & Canine & $14(70 \%)$ & $6(30 \%)$ & & \\
\hline & & Premolar & $114(80.3 \%)$ & $28(19.7 \%)$ & & \\
\hline & & Molar & $34(70.8 \%)$ & $14(29.2 \%)$ & & \\
\hline & \multirow{4}{*}{ Inadequate } & Incisor & $70(50 \%)$ & $70(50 \%)$ & $1.279(0.886-1.847)$ & \multirow[t]{4}{*}{$0.001^{*}$} \\
\hline & & Canine & $44(64.7 \%)$ & $24(35.3 \%)$ & $0.642(0.382-1.078)$ & \\
\hline & & Premolar & $158(63.2 \%)$ & $92(36.8 \%)$ & $0.606(0.444-0.826)$ & \\
\hline & & Molar & $146(48.3 \%)$ & $156(51.7 \%)$ & $1.563(1.166-2.094)$ & \\
\hline \multirow{8}{*}{ Mandible } & \multirow{4}{*}{ Adequate } & Incisor & $20(71.4 \%)$ & $8(28.6 \%)$ & $0.834(0.350-1.987)$ & \multirow[t]{4}{*}{$0.002^{*}$} \\
\hline & & Canine & $4(100 \%)$ & $0(0 \%)$ & - & \\
\hline & & Premolar & $68(81 \%)$ & $16(19 \%)$ & $0.372(0.198-0.699)$ & \\
\hline & & Molar & $74(57.8 \%)$ & $54(42.2 \%)$ & $2.797(1.582-4.946)$ & \\
\hline & \multirow{4}{*}{ Inadequate } & Incisor & $14(70 \%)$ & $6(30 \%)$ & $0.387(0.146-1.025)$ & \multirow[t]{4}{*}{$0.000^{\star}$} \\
\hline & & Canine & $22(68.8 \%)$ & $10(31.3 \%)$ & $0.403(0.187-0.869)$ & \\
\hline & & Premolar & $106(63.1 \%)$ & $62(36.9 \%)$ & $0.404(0.275-0.593)$ & \\
\hline & & Molar & $98(35.5 \%)$ & $178(64.5 \%)$ & $3.307(2.283-4.788)$ & \\
\hline
\end{tabular}

Chi-Square test $/{ }^{*} p<0.05$

\section{DISCUSSION}

The technical quality of root canal filling is related to many factors, such as the distance between the obturation material and the radiographic apex, the density of obturation, taper of mechanical preparation and iatrogenic errors [22]. The underfilled and overfilled root canal obturations with voids may threat the treatment success. These mishaps increase the risk of bacterial leakage or periradicular tissue irritation, resulting with AP. Moreover adequate preparation taper has an important impact on the removal of debris and smear layer from the canal walls [23,24]. These parameters were our examination criterias because of their direct effect on AP.

General dental examination includes intraoral, extraoral and radiographic examination. For routine radiographic examination, panoramic radiographs provide a general view of dentomaxillomandibular structures that render all teeth and restorations visible in relatively low radiation dose radiographs [25]. On the other hand, panoramic radiographs may not provide high enough definition and sufficient information of the status of the periradicular tissues, and apical periodontitis can be misread, along with the coronal status of the teeth in panoramic radiographs [26]. In our study, periapical radiographs were used to examine the radiographic quality of RCT based on various parameters, as performed in previous studies [27,28]. Many previous studies on the prevalence of AP have used periapical radiographs due to their high accuracy $[29,30]$. In addition, three dimensional imaging technique cone-beam computed tomography (CBCT) has been shown to yield very accurate outcomes as a new imaging method. However, this imaging techique is rarely justified in routine dental examination, but rather is used in more specialized cases [31].

The technical quality of root canal obturation is considered to be one of the most essential factors for success in root canal treatment. Adequate obturations in our study were found to be $29.4 \%$, which is lower than the range of most other published studies. This can be explained by examining "taper quality" as an additional criterion for root canal filling quality, along with obturation length and density [2,28,32]. According to our results, among all the examined teeth, $56.7 \%$ of the obturations had voids, $53.4 \%$ had inadequate taper quality and $44.4 \%$ had underfilled obturation length, which caused $70.6 \%$ inadequate obturation quality. In fact, Kielbassa et al. [32] and $\mathrm{Ng}$ et al. [5] found similar results to those in our study concerning root canal filling quality. Moreover, both maxillary and mandibular canine and molar teeth tend to have inadequate obturation quality, according to our results. The most 
logical explanation for this failure in molars is that these teeth have multiple root canals with complex anatomies and mostly curved roots. In addition, molar teeth being located on the posterior areas of the jaws make them difficult to reach and eliminate from the intraoral tissues during endodontic treatment. On the other hand, canine teeth are singlerooted and mostly have a wide root canal chamber and are relatively easy to access, but the very specific anatomical difference from other single-rooted teeth is root length, which is usually much longer than the others, which results in underfilled obturations.

Criterias for radiographic assessment of AP vary among authors and studies [29,33]. Since PAI scoring technique by Ørstavik et al. [21] doesn't allow clinical judgement in the evaluation of AP, it has higher reproducibility so, different researches can easily be compared. This study also evaluated the periapical status using PAI scoring technique suggested by Ørstavik et al. [21] On the other hand, PAI score 2 may cause diagnostic challenges on determining clinical success or failure because this score may be serving a stable condition of an endodontically treated teeth's periapex. Moreover persistent PAI score 3 would demonstrate periapical pathology whether the tooth is endodontically treated or not [7].

Studies have shown that obturation quality affects periapical status [17,34]. We found a statistically significant correlation between obturation quality and periapical status in our study. Inadequate fillings with 2,3 and 4 PAI scores were significantly higher than adequate ones with 2, 3 and 4 PAI scores. Differently, Song et al. [29] reported no significant correlation between the percentage of AP in teeth with inadequate root canal obturations. This result may be related to the evaluation of both coronal restoration and obturation quality while including less obturation quality criterias compared to our study.

The most frequent PAI score of obturated teeth was 2 following 1 in this study. In contrast Kirkevang et al. [11], Ilıc et al. [14] and Da Silva et al. [35] found that PAI score of 3 was the most common among root canal treated teeth. The present study demonstrated that the odds ratio for AP with inadequate obturations was increased by $2.45 \%$ when compared to those with adequate obturations. Kielbassa et al. [32] also found the odds ratio to have increased in their study. In addition, in our study, adequately obturated teeth were found to have a markedly lower frequency of AP than inadequately obturated teeth, and this association seems to confirm other studies $[32,36]$.

The present study showed that overfilled and under-filled root canal obturations, fillings with voids and inadequate taper quality increase the risk of AP. Vengerfeldt et al. [37] found that the percentage of AP in underfilling and overfilling is more than $50 \%$, which is similar to the results of our study. Underfilled obturations have unprepared regions in root canals, while overfilled obturations might cause foreign body reactions. AP may occur under the conditions outlined above. Up to $91.9 \%$ obturations with no voids radiographically were reported in the literature [29,36,37] while we found this percentage to be 43.3 $\%$ in our study. Moreover, the percentage of teeth with no AP and no voids within the root canal obturation was recorded as $70.6 \%$. This result demonstrates that the presence or absence of voids affects periapical status. However, the effect of the density of the fillings on periapical status has been debated $[25,38]$. More studies about the effect of the density of root canal fillings on periapical status is necessary for clinical vigilance. Other parameters which we examined in this study were taper quality and iatrogenic errors. Inadequate taper quality and iatrogenic errors negatively affected periapical status 2.11 times and 1.56 times, respectively. To our knowledge, there have been no cross-sectional studies on the association between periapical status and taper quality; increased focus on this parameter is therefore recommendable in further studies. 
The relationship between the quality of root canal treatment and periapical status according to tooth type and location has been shown in a small number of cross-sectional studies $[39,40]$. Our study demonstrates that anterior and molar teeth with inadequate obturation were found to have 1.27 and 1.56 times more AP risk than other teeth in maxilla, respectively. Kirkevang et al. [11] also showed that the frequency of endodontically treated teeth with AP is significantly higher in molar teeth, followed by anteriors and premolars, with which our study is in accordance. However the mentioned study did not examined the radiographic quality of root canal treatments. This difference of methodology makes comparison between these two studies irrelevant. Ridell et al. [40] likewise reported on the periapical status of endodontically treated teeth without judging present endodontic treatments as "adequate" or "inadequate". According to their study results, molar teeth tend to have a higher risk of AP than the anteriors. In addition, both of these studies failed to examine periapical status according to tooth location as maxilla and mandible, in contrast to our study.

Our results show that, whether obturation quality is "adequate" or "inadequate", molar teeth have been found to have markedly AP in mandible. This result supports the idea that not only the radiographic obturation quality but also procedural quality during endodontic treatment is required for successful pathology elimination and healing process. In addition, having vital or necrotic pulp at the the beginning of root canal treatment may also be considered as another factor affecting periapical status. Since our study being a cross-sectional retrospective research; this matter will be evaluated in further studies.

\section{CONCLUSION}

The frequency of inadequate root canal obturations of endodontically treated teeth of the selected Turkish population was high, especially in molar teeth and women. On the other hand, periapical status had positive correlation with the radiological quality of root canal fillings. The majority of the evaluated teeth, whether the obturation was adequate or inadequate scored as PAI 1, following PAI 2. The current study showed that the technical quality of endodontic treatment should be improved by practicioners to increase success. Due to the highly specific parameters of recent studies, further studies with similar parameters and evaluations are needed to correlate with our study.

\section{REFERENCES}

1. Möller AJ, Fabricius L, Dahlén G, Sundqvist G, Happonen RP.Apical periodontitis development and bacterial response to endodontic treatment. Experimental root canal infections in monkeys with selected bacterial strains. Eur J Oral Sci. 2004 Jun;112(3):207-15

2. Al-Omari MA, Hazaa A, Haddad F. Frequency and distribution of root filled teeth and apical periodontitis in a Jordanian subpopulation. Oral Surg Oral Med Oral Pathol Oral Radiol Endod. 2011 Jan;111(1):e59-65. Doi:10.1016/j. triple0.2010.08.007.

3. Alfouzan K, Baskaradoss JK, Geevarghese A, Alzahrani M, Alhezaimi K. Radiographic diagnosis of periapical status and quality of root canal fillings in a Saudi Arabian subpopulation. Oral Health Prev Dent. 2016;14(3):241-8. doi: 10.3290/j.ohpd.a35299

4. Meirinhos J, Martins JNR, Pereira B, Baruwa A, Gouveia J, Quaresma SA, et al. Prevalence of apical periodontitis and its association with previous root canal treatment, root canal filling length and type of coronal restoration -a cross-sectional study. IntEndod J. 2019 Nov 20. doi: 10.1111/iej.13256. [Epub ahead of print]

5. Ng YL, Mann V, Gulabivala K. Outcome of secondary root canal treatment:a systematic review of the literature. IntEndod J. 2008 Dec;41(12):1026-46. Doi: 10.1111/.j.1365-2591.2008.01484.x.

6. Eriksen HM, Kirkevang LL, Petersson K. Endodontic epidemiology and treatment outcome: general considerations. Endod Top 2002;2(1):1-9. doi:https://doi.org/10.1034/j.1601-1546.2002.20101.x

7. Kirkevang LL, Ørstavik D, Hörsted-Bindslev P,Wenzel A. Periapical status and quality of root fillings and coronal restorations in a Danish population. Int Endod J.2000 Nov;33(6):509-15.

8. Siqueira JFJr, Rôças IN, Alves FR, Campos LC. Periradicular status related to the quality of coronal restorations and root canal fillings in a Brazilian population. Oral Surg Oral Med Oral Pathol Oral Radiol Endod. 2005 Sep;100(3):369-74.

9. Torabinejad M, Kettering JD, McGraw JC, Cummings RR, Dwyer TG, Tobias TS Factors associated with endodontic interappointment emergencies of teeth with necrotic pulps. JEndod. 1988 May;14(5):261-6

10. Friedman S. Treatment outcome and prognosis of endodontic therapy. In: Orstavik D, PittFord TR, eds. Essential endodontology: Prevention and treatment of apical periodontitis. Oxford, UK: Blackwell Science; 1998. p.367401. 
11. Kirkevang LL, Hörsted-Bindslev P,Orstavik D, Wenzel A. A comparison of the quality of root canal treatment in two Danish subpopulations examined 197475 and 1997-98. Int Endod J.2001Dec;34(8):607-12

12. Sjogren U, Hagglund B, Sundqvist G, Wing K. Factors affecting the long-term results of endodontic treatment. JEndod. 1990 0ct;16(10):498-504

13. Eriksen HM, Bjertness E. Prevalence of apical periodontitis and results of endodontic treatment in middle-aged adults in Norway. Endod Dent Traumatol. 1991 Feb;7(1):1-4.

14. Ilić J, Vujašković M, Tihaček-Šojić L, Milić -Lemić A. Frequency and quality of root canal fillings in an adult Serbian population. Srp Arh Celok Lek. 2014 Nov-Dec;142(11-12):663-8

15. Loftus JJ, Keating AP,McCartan BE. Periapical status and quality of endodontic treatment in an adult Irish population. IntEndod J.2005 Feb;38(2):81-6.

16. Lupi-Pegurier L, Bertrand MF,Muller-Bolla M, Rocca JP,Bolla M. Periapical status, prevalence and quality of endodontic treatment in an adult French population. IntEndod J. 2002 Aug;35(8):690-7

17. Tavares PB, Bonte E, Boukpessi T, Siqueira JF Jr, Lasfargues JJ. Prevalence of apical periodontitis in root canal-treated teeth from an urban French population: influence of the quality of root canal fillings and coronal restorations. JEndod. 2009 Jun;35(6):810-3. doi:10.1016/j.joen.2009.03.048

18. Kirkevang LL, Wenzel A. Risk indicators for apical periodontitis. Community Dent Oral Epidemiol. 2003 Feb;31(1):59-67.

19. Consensus report of the European Society of Endodontology on quality guidelines for endodontic treatment. IntEndod J. 1994 May;27(3):115-24.

20. Barrieshi-Nusair KM, Al-Omari MA, Al-Hiyasat AS. Radiographic technical quality of root canal treatment performed by dental students at the Dental Teaching Center in Jordan. JDent. 2004 May;32(4):301-7

21. Orstavik D, Kerekes K, Eriksen HM. The periapical index: a scoring system for radiographic assessment of apical periodontitis. Endod Dent Traumatol. 1986 Feb;2(1):20-34

22. Rafeek RN, Smith WA, Mankee MS, Coldero LG. Radiographic evaluation of the technical quality of root canal fillings performed by dental students. Aust Endod J.2012 Aug;38(2):64-9. doi: 10.1111/j.1747-4477.2010.00270.x.

23. Young GR, Parashos P,Messer HH. The principles of techniques for cleaning root canals. Aust Dent J. 2007 Mar;52(1Suppl):S52-63.

24. Buchanan LS. The standardized-taper root canal preparation--Part1.Concepts for variably tapered shaping instruments. Int Endod J. 2000 Nov;33(6):516-29.

25. Rohlin M, KullendorffB, Ahlqwist M, Henrikson CO, Hollender L, Stenström B. Comparison between panoramic and periapical radiography in the diagnosis of periapical bone lesions. Dentomaxillofac Radiol. 1989 Nov;18(4):151-5

26. Dahlström L, Lindwall 0, Rystedt H, Reit C. It's good enough': Swedish general dental practitioners on reasons for accepting substandard root filling quality. IntEndod J. 2018 Apr;51Suppl 3:e168-e177. doi: 10.1111/iej.12743.

27. De Moor RJG, Hommez GMG, De Boever JG, Delme KIM, Martens GEl. Periapical health related to the quality of root canal treatment in a Belgian population. IntEndod J 2000;33:113-20. De Moor RJ, Hommez GM, De Boever JG, Delmé KI, Martens GE. Periapical health related to the quality of root canal treatment in a Belgian population. IntEndod J. 2000 Mar;33(2):113-20.
28. Boucher Y,Matossian L, RilliardF,Machtou P.Radiographic evaluation of the prevalence and technical quality of root canal treatment in a French subpopulation. IntEndod J. 2002 Mar;35(3):229-38.

29. Song M, Park M, Lee CY, KimE. Periapical status related to the quality of coronal restorations and root fillings in a Korean population. J Endod. 2014 Feb;40(2):182-6. doi: 10.1016/j.joen.2013.10.017.

30. Georgopoulou MK, Spanaki-Voreadi AP,Pantazis N, Kontakiotis EG. Frequency and distribution of root filled teeth and apical periodontitis in a Greek population. IntEndod J. 2005Feb;38(2):105-11

31. Venskutonis T,Plotino G, Juodzbalys G, Mickevi ien L. The importance of conebeam computed tomography in the management of endodontic problems: a review of the literature. JEndod.2014 Dec;40(12):1895-901. doi:101016/j. joen.2014.05.009.

32. Kielbassa AM, Frank W, Madaus T. Radiologic assessment of quality of root canal fillings and periapical status in an Austrian subpopulation - An observational study. PLoS One. 2017 May 2;12(5):e0176724. Doi:101371/journal. pone.0176724.

33. Kayahan MB, Malkondu 0, Canpolat C, Kaptan F,Bayirli G, KazazogluE. Periapical health related to the type of coronal restorations and quality of root canal fillings in a Turkish subpopulation. Oral Surg Oral Med Oral Pathol Oral Radiol Endod. 2008 Jan;105(1):e58-62.

34. Dugas NN, Lawrence HP, Teplitsky PE, Pharoah MJ, Friedman S. Periapical health and treatment quality assessment of root-filled teeth in two Canadian populations. Int Endod J. 2003 Mar;36(3):181-92

35. Da Silva K, Lam JM, Wu N, Duckmanton P.Cross-sectional study of endodontic treatment in an Australian population. Aust Endod J.2009 Dec;35(3):140-6. Doi: 10.1111/j.1747-4477.2009.00215.x.

36. Hussein FE, Liew AK, Ramlee RA, AbdullahD, Chong BS. Factors associated with apical periodontitis: A multilevel analysis. J Endod 2016;42:1441-5. Hussein FE, Liew AK, Ramlee RA, AbdullahD, Chong BS. Factors associated with apical periodontitis: a multilevel analysis. J Endod. 2016 0ct;42(10):1441-5. doi: 10.1016/j.joen.2016.07.009

37. Vengerfeldt V,Mändar R, Nguyen MS, Saukas S, Saag M. Apical periodontitis in southern Estonian population: prevalence and associations with quality of root canal fillings and coronal restorations. BMC Oral Health. 2017 Dec 12;17(1):147. doi:10.1186/s12903-017-0429-7.

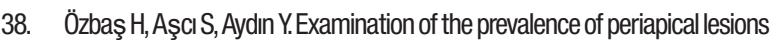
and technical quality of endodontic treatment in a Turkish subpopulation. Oral Surg Oral Med Oral Pathol Oral Radiol Endod. 2011 Jul;112(1):136-42. doi:10.1016/j. triple0.2011.01.010.

39. Matijević J,Cizmeković Dadić T,Prpic Mehicic G, Anil, Slaj M, Jukić Krmek S. Prevalence of apical periodontitis and quality of root canal fillings in population of Zagreb, Croatia: a cross-sectional study. Croat Med J. 2011Dec 15;52(6):67987.

40. Ridell K, Petersson A, Matsson L, Mejàre I. Periapical status and technical quality of root-filled teeth in Swedish adolescents and young adults. A retrospective study. Acta Odontol Scand. 2006 Apr;64(2):104-10

\section{Tuna Kaplan}

(Corresponding address)

Department of Endodontics, Faculty of Dentistry, Biruni University, 10. Y1l

Caddesi, Protokol Yolu, No: 45, 34010, Topkap1 / Istanbul / Turkey

Date submitted: 2019 Sep 18

E-mail: tkaplan@biruni.edu.tr
Accept submission: 2020 Jan 28 